\title{
Preliminary results with a torsion microbalance indicate that carbon dioxide and exposed carbonic anhydrase in the organic matrix are the basis of calcification on the skeleton surface of living corals
}

\author{
Ian M. Sandeman ${ }^{1}$ \\ 1. Dept. of Biology, Trent University, Peterborough, Ontario, K9J 7B8, Canada; isandem@ pipcom.com or \\ isandeman@trentu.ca
}

\author{
Received 23-VI-2011. C Corrected 14-XII-2011. Accepted 20-XII-2011.
}

\begin{abstract}
Ocean acidification is altering the calcification of corals, but the mechanism is still unclear. To explore what controls calcification, small pieces from the edges of thin plates of Agaricia agaricites were suspended from a torsion microbalance into gently stirred, temperature controlled, seawater. Net calcification rates were monitored while light, temperature and $\mathrm{pH}$ were manipulated singly. The living coral pieces were sensitive to changes in conditions, especially light, and calcification was often suspended for one or two hours or overnight. The mean calcification rate increased from 0.06 in the dark to $0.10 \mathrm{mg} \cdot \mathrm{h}^{-1} \cdot \mathrm{cm}^{-2}$ ( $\mathrm{T}$ test, $\mathrm{n}=8, \mathrm{p}<0.01$ ) in low light $\left(15 \mu \mathrm{mol} . \mathrm{s}^{-1} \cdot \mathrm{m}^{-2}\right)$ and showed a positive linear relationship with temperature. With a reduction of mean $\mathrm{pH}$ from 8.2 to 7.6 the mean calcification rate in the light $\left(65 \mu \mathrm{mol} . \mathrm{s}^{-1} . \mathrm{m}^{-2}\right)$ increased from 0.19 to 0.28 $\mathrm{mg} \cdot \mathrm{h}^{-1} . \mathrm{cm}^{-2}$ (T test, $\left.\mathrm{n}=8, \mathrm{p}<0.05\right)$ indicating a dependency on carbon dioxide. After waterpiking and exposure of the skeletal surface/organic matrix to seawater, calcification showed an astonishing initial increase of more than an order of magnitude then decreased following a non-linear generalised Michaelis-Menten growth curve and reached a steady rate. Calcification rate of the freshly waterpiked coral was not influenced by light and was positively correlated with temperature. For a mean $\mathrm{pH}$ reduction from 8.1 to 7.6 the mean calcification rate increased from 0.18 to $0.32 \mathrm{mg} \cdot \mathrm{h}^{-1} \cdot \mathrm{cm}^{-2}$ ( $\mathrm{T}$ test, $\mathrm{n}=11, \mathrm{p}<0.02$ ) again indicating a dependency on carbon dioxide. Calcification ceased in the presence of the carbonic anhydrase inhibitor azolamide. Staining confirmed the presence of carbonic anhydrase, particularly on the ridges of septae. After immersion of waterpiked corals in seawater for 48 hours weight gain and loss became linear and positively correlated to temperature. When the mean $\mathrm{pH}$ was reduced from 8.2 to 7.5 the mean rate of weight gain decreased from 0.25 to $0.13 \mathrm{mg} \cdot \mathrm{h}^{-1} . \mathrm{cm}^{-2}(\mathrm{~T}$ test, $\mathrm{n}=6, \mathrm{p}<0.05$ ) indicating a dependence on carbonate. At a $\mathrm{pH}$ of 6.5 the skeleton lost weight at a rate of 1.8 $\mathrm{mg} \cdot \mathrm{h}^{-1} \cdot \mathrm{cm}^{-2}$. The relationship between net calcification and $\mathrm{pH}(\mathrm{n}=2)$ indicates that wt gain turns to loss at $\mathrm{pH}$ 7.4. These experiments confirm that calcification is a two-step process, involving secretion of a layer of organic matrix incorporating carbonic anhydrase to produce an active calcifying surface which uses carbon dioxide rather than carbonate. It is also unlikely that the calcifying surface is in direct contact with seawater. Inorganic deposition or dissolution of the skeleton in exposed dead areas of coral is a different phenomenon and is carbonate related. The wide range in results from this and other studies of calcification rate and carbon dioxide may be explainable in terms of the ratio of "live" to "dead" areas of coral. Rev. Biol. Trop. 60 (Suppl. 1): 109-126. Epub 2012 March 01.
\end{abstract}

Key words: coral calcification, $\mathrm{CO}_{2}, \mathrm{pH}$, temperature, organic matrix, carbonic anhydrase.

The processes involved in the production of an aragonite $\left(\mathrm{CaCO}_{3}\right)$ skeleton in corals are poorly known compared to calcification in other animals (Allemand et al. 2011). Seawater contains about $10.3 \mathrm{mmol} . \mathrm{kg}^{-1}$ of calcium ions $\left(\mathrm{Ca}^{2+}\right)$, dissolved inorganic carbon is present in seawater as carbon dioxide $\left(\mathrm{CO}_{2}\right)$, carbonic acid $\left(\mathrm{H}_{2} \mathrm{CO}_{3}\right)$, bicarbonate $\left(\mathrm{HCO}_{3}^{-}\right)$and carbonate $\left(\mathrm{CO}_{3}^{2-}\right)$, with the equilibria between them described by their equilibrium constants and their relationships with $\mathrm{pH}$, alkalinity and temperature. What is still not clear is in what form dissolved inorganic carbon (DIC) reaches the site of calcification, how DIC and $\mathrm{Ca}^{2+}$ get 
there and to what extent, if at all, the calcifying surface is in direct contact with seawater. It seems to have been taken for granted that the formation of aragonite crystals would result from the combination of $\mathrm{Ca}^{2+}$ and $\mathrm{CO}_{3}{ }^{2-}$ dissolved in seawater. However, Lee et al. (2010) have reported crystalline aragonite deposition from a solution of $\mathrm{CaCl}_{2}$ containing carbonic anhydrase using $\mathrm{CO}_{2}$ directly from the atmosphere. The sources of calcium and carbon and how they reach the calcification site have been reviewed by Cohen \& McConnaughey (2003), Furla et al. (2000) and Allemand et al. (2004) and Allemand et al. (2011). Carbon-dioxide which can move freely through cell membranes was proposed by McConnaughey (1989) as a substrate for calcification to account for ${ }^{18} \mathrm{O}$ and ${ }^{13} \mathrm{C}$ deficiencies in coral skeletons (McConnaughey, 2000). The response of corals to changes in $\mathrm{CO}_{2}$ partial pressure and temperature was reviewed by Reynaud et al. (2003). While calcification and photosynthesis may compete for the same DIC pool they are sometimes regarded as complementary (Gattuso et al. 1999) rather than in competition (Langdon \& Atkinson, 2005). With a focus on ocean acidification as the result of increased anthropogenic carbon dioxide in the atmosphere, calcification has been increasingly linked to the calcium-carbonate saturation state $(\Omega)$ which is the ratio of the ion concentration product $\left(\left[\mathrm{Ca}^{2+}\right] \times\left[\mathrm{CO}_{3}{ }^{2-}\right]\right)$ to the solubility product of the mineral deposited, in this case aragonite (Allemande et al. 2004). As acidity increases the relative concentration of carbonate in seawater is reduced and has been used to predict decreased calcification at the organism and community levels (Kleypas et al., 1999; Gattuso et al., 1999, Marubini \& Thake, 1999, Langdon, 2000, Langdon et al., 2000 Langdon et al. 2003 and Erez et al. 2011). However problems have emerged with the link between calcification and carbonate concentration or saturation state (Jury et al 2010, De Putron et al. or with the predictions that have followed. From the banding of Florida corals from 1937 to 1996 Helmle et al., 2011 found that calcification was stable and the average rate during the most recent decade was not significantly different from those of the preceding 5 decades. Fabricius et al. (2011) found that as $\mathrm{pH}$ declined from 8.1 to 7.8 (the expected change by the end of the century), found reductions in coral diversity but not all corals were affected. Krief et al. 2010 kept coral fragments in controlled aquarium conditions with normal and raised $\mathrm{CO}_{2}$ levels equivalent to $\mathrm{pH}$ values of 8.09, 7.49 and 7.19 and the fragments all survived and added new skeleton. The Mediterranean coral Cladocera in low pH level did not show predicted reduced calcification (RodolfoMetalpa et al. 2010, 2011). There is a lot of information on the growth and dissolution kinetics of finely divided aragonite (Gutjahr et al., 1996, Cubillas, 2005) but little information on how dead coral behaves. Rodolfo-Metalpa et al.(2011) found that dead corals did not dissolve at a $\mathrm{pH}$ of 7.8 and measured dissolution rates at $\mathrm{pH} 7.4\left(0.3-0.6 \mathrm{mg} \cdot \mathrm{g}^{-1} \cdot \mathrm{d}^{-1}\right)$ and 6.8 (3.7-4.2 mg.g $\left.{ }^{-1} \cdot \mathrm{d}^{-1}\right)$. Rodolfo-Metalpa et al., (2011) suggested that coral tissues protect the skeletons from corrosive $(\Omega<1)$ seawater. Villegas-Jiminez et al. (2009) reported large consistent proton $/ \mathrm{Ca}^{2+}$ exchanges which may have far reaching implications for the interpretation of kinetic and equilibrium exchanges. As the growth and dissolution kinetics are similar for calcite and aragonite (Gutjahr et al., 1996) the same problems of interpretation are likely to exist for aragonite.

Active calcification in scleratinian corals is a two stage process which involves secretion of a layer of organic matrix (reviewed by Allemand et al.1998 and Allemand et al. 2011) and calcium carbonate, crystallized in the form of aragonite, is deposited in the organic matrix with the involvement of structural proteins with a catalytic role similar to that of carbonic anhydrase (Tambutté et al. 2007), calcium binding compounds (Isa \& Okazaki, 1987, Constantz \& Wiener 1988 and Puverel et al. 2005) and proteins regulating the biomineralization process along with $\mathrm{Mg}^{2+}$ which inhibits calcite formation (Rahman \& Oomori, 2009). Aragonite deposition takes place from the extracellular calcifying fluid (ECF) or hydrogel-like 
medium (ECM) (Bryan \& Hill, 1941 and Cuif et al. 2004a) onto the organic matrix framework on the surface of the skeleton. Charged ions such as $\mathrm{Ca}^{2+}, \mathrm{HCO}_{3}{ }^{-}$and $\mathrm{CO}_{3}{ }^{2-}$ cannot move passively through cell membranes so either active transport via a transcellular route, passive diffusion of ions or seawater using a paracellular route at the boundaries of cells, or some combination of these routes may be involved (Allemand et al. 2011, Cohen \& McConnaughey, 2003). $\mathrm{Ca}^{2+}$, for example, may arrive from the calicoblastic layer as the result of the $\mathrm{Ca}^{2+}$ ATPase pump such that protons are moved in the opposite direction enhancing the diffusion of $\mathrm{CO}_{2}$ to the ECM (Adkins et al. 2003, Sandeman, 2008a). Allemand et al. 2011 reviewed the possible light enhancement mechanisms for calcification. The range of ratios observed for calcification rates in the light versus in the dark is large and the median value of enhanced calcification in light (LEC) is around 3 (Gattuso et al. 1999).

Calcification rates of corals are commonly derived by buoyant weighing techniques (Davies, 1989), uptake of the radioactive isotope ${ }^{45} \mathrm{Ca}$ ( eg Moya et al. 2006, Al-Horani, 2007), the alkalinity anomaly technique (Smith \& Key, 1975) or using a sclero-chronological technique (eg by Gischler \& Oschmann 2005). Each of these methods has its advantages and disadvantages, with some requiring destruction of the coral. The buoyant weighing technique used by Franzisket (1964) and developed by Davies (1989) for nubbins of Porites porites has been used to measure calcification rates over time periods of less than a day. In physiological studies one disadvantage of this technique is that the coral or a coral 'nubbins' has to be transferred to and from a balance for weighing. For physiological experiments over shorter time periods it is desirable to minimise any physical disturbance and provide stable conditions while still being able to change experimental parameters such as light, temperature or $\mathrm{pH}$. Analytical balances are expensive, sensitive to sea air and because they tend to drift they may require re-zeroing regularly which requires disturbing the organism. For this study, a stable torsion microbalance was developed, following Kesling \& Crafts (1962), from which small pieces of coral could be continuously suspended in seawater for periods of several hours or days while the seawater medium was manipulated, a parameter at a time, with minimum disturbance to the coral. Kesling \& Crafts (1962) outlined the physics of the torsion balance. In our version of the balance the beam and lengths of wire are used are shorter and piano wire was replaced with thinner wire of stainless steel, tungsten or silicon carbide with a central core of tungsten, all of which were found to be less affected by seawater. Mirrors and laser beams were used to achieve magnification of the angular rotation of the torsion wire. Early evaluation indicated that wire of $0.05-0.15 \mathrm{~mm}$ gave a satisfactory sensitivity, that tension did not effect the sensitivity but the sensitivity decreased with heavier pieces of coral. Davies (1989) established with his buoyant weighing technique that changes in coral tissue weight over the time span of an experiment were small and could be corrected for, and could be ignored altogether for imperforate corals such as Agaricia. A method was developed for calibration of the balance without the need to apply the complex equations (Davies, 1989 and Jokiel et al, 1978) used for determining the air weight of coral skeleton from its weight in seawater.

This study was started initially to test and improve the balance and to evaluate its potential for the measurement of weight change in coral calcification. The method clearly has major limitations in that the system is open and the seawater medium can exchange $\mathrm{CO}_{2}$ with the air. Also, removal of water for analysis changes the water level and interferes with balance function, the only means available of monitoring chemistry of the seawater in situ was with a $\mathrm{pH}$ probe. Thus with the system open to the air it can only provide an approximate indication of the carbonate status of the seawater. The aims of the study were to compare net calcification of live coral, of the skeleton after removal of the tissue and of dead coral, and to investigate how net calcification 
varies with temperature, irradiance and $\mathrm{pH}$, the latter with a potential to indicate whether $\mathrm{CO}_{2}$ or $\mathrm{CO}_{3}{ }^{2-}$ are used as the substrate for calcification. The early results were so unexpected, and had the potential to contribute to mechanisms of calcification that in spite of the limitations of the methods and the fact that time constraints meant that some experiments were not repeated, it seemed important to communicate the results more widely.

\section{MATERIALS AND METHODS}

Small pieces of Agaricia agaricites were snipped from the edge of thin plates of young colonies growing near the reef crest opposite the Discovery Bay Marine Laboratory. The pieces were immediately transported to the seawater tables where they were trimmed to a suitable size $\left(1-2 \mathrm{~cm}^{2}\right)$ then suspended by loops of thin $(0.025$ $\mathrm{mm}$ diam.) polyester monofilament in gently flowing seawater that had been passed through frequently changed filters of cheesecloth and activated charcoal. The coral pieces were held for two or three days until used, in a regime of dark (6.30pm-6.30am) and light (6.30am$6.30 \mathrm{pm})$ at about $200 \mu \mathrm{mol}$ photons under a mercury halide floodlight (Philips 25W, 25 ${ }^{\circ}$ ). Seawater used in the experimental chambers was collected from outside the bay on the fore reef, passed through activated charcoal and millepore filtered $(0.45 \mu)$. Salinity was measured with a Pinpoint Salinity Monitor (American Marine Inc.). Total Alkalinity of the seawater was not measured directly but was estimated from salinity using a formula for northern Caribbean waters $(\mathrm{TA}=57.3 \times$ Sal. $+296.4 \pm 19.3)$ from Cai et al .

TABLE 1

Estimated carbon parameters for the seawater used in experiments

\begin{tabular}{lcccc}
\multicolumn{1}{c}{ Parameter } & \multicolumn{2}{c}{$\begin{array}{c}\text { Control } \mathrm{pH} \\
\text { (means) }\end{array}$} & \multicolumn{2}{c}{$\begin{array}{c}\text { Treatment } \mathrm{pH} \\
\text { (Means) }\end{array}$} \\
$\mathrm{pH}(\mathrm{NBS})$ & 8.2 & 8.1 & 7.6 & 7.5 \\
$\mathrm{CO}_{2}\left(\mu \mathrm{mol} \mathrm{kg}{ }^{-1}\right)$ & 10.1 & 13.4 & 49.7 & 63.6 \\
$\left.\mathrm{CO}_{3}^{2-}(\mu \mathrm{mol} \mathrm{kg})^{-1}\right)$ & 241.5 & 202.5 & 75 & 60.5 \\
$\Omega_{\text {arag }}$ & 3.9 & 3.25 & 1.2 & 0.97 \\
\hline
\end{tabular}

(2010). $\left[\mathrm{CO}_{2}\right],\left[\mathrm{CO}_{3}{ }^{2-}\right]$ and $\Omega$ were estimated (Table 1) using the CO@SYS program (Lewis and Wallis 1998) and the NBS Buffer scale.

For all experiments, single pieces of coral were suspended by the monofilament loop and a 5-6 cm length of $0.05 \mathrm{~mm}$ diam. stainless steel $(\mathrm{s} / \mathrm{s})$ wire from the beam of the torsion balance (Fig. 1) into a vessel with 1 or 21 of seawater that had been passed through activated charcoal and millepore filtered $(0.45 \mu)$. The temperature of the water in the chamber except where otherwise stated was maintained at $28^{\circ} \mathrm{C}$ and was regulated to within $0.1^{\circ} \mathrm{C}$ by a temperature sensing thermistor, regulator circuit

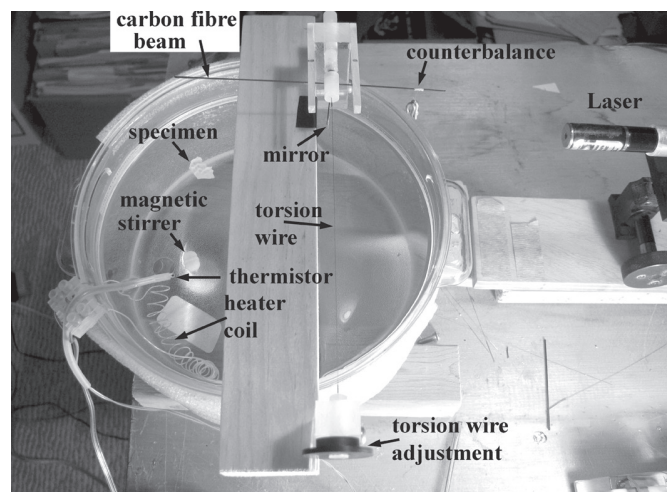

Fig. 1. The torsion balance. The ends of a $15 \mathrm{~cm}$ length of torsion wire (tungsten, diam. $0.05-0.15 \mathrm{~mm}$ ) are embedded in short pieces of stainless steel tubing $(0.5 \mathrm{~mm}$ OD) with cyanoacrylate. One end is held by friction fit in a polyethylene cylinder which can be rotated in its mount (torsion wire adjustment). The other end of the torsion wire is inserted into a $1 \mathrm{~cm}$ cylinder (diam. $0.62 \mathrm{~cm}$ ) of low density polyethylene with a cylindrical rare earth magnet $(0.31 \times 0.31 \mathrm{~cm}$ diam. $)$ embedded in its other end. The wire is held under tension by a second similar magnet embedded in the end of a threaded $6.35 \mathrm{~mm}$ diam. polyethylene rod. This rod can be turned to change the separation between the two magnets. A carbon fibre beam is inserted through a hole drilled through the polyethelyene cylinder at right angles to the torsion wire. A second carbon fibre rod inserted into the polyethylene cylinder supports a small piece $(2 \times 4 \mathrm{~mm})$ of thin cover glass which acts as a mirror. On one end of the beam is a small vertical wire hook from which coral samples can be suspended. The other end of the beam supports a small weight that can be slid along the beam and acts as a counterbalance. The beam from a laser pointer is reflected by the mirror on to a scale at a distance of about $3 \mathrm{~m}$ and enables rotation of the torsion wire to be measured. 
and insulated heater coil. A small magnetic stirrer $(1.0 \times 0.7 \mathrm{~cm})$ gently and continuously circulated the water in the vessel. The $\mathrm{pH}$ was changed by adding hydrochloric acid (adjusted to the density of seawater), or by exchanging some of the seawater in the vessel with seawater that had a high dissolved $\mathrm{CO}_{2}$ or $\mathrm{NaCO}_{3}$ content. For higher $\mathrm{pH}$ levels water in the vessel was exchanged with seawater that had been bubbled with $\mathrm{CO}_{2}$ free air. A pH meter (IQ200, Scientific Instruments), accurate to 2 decimal places, and calibrated daily, was used to monitor changes of $\mathrm{pH}$. Room lighting was 15 $\mu \mathrm{mol} . \mathrm{s}^{-1} \cdot \mathrm{m}^{-2}$ and additional light was provided by a metal halide spotlight (Philips $25 \mathrm{~W}, 10^{\circ}$ ) above the beaker. Irradiance levels were measured with a LI-COR Quantum/Radiometer (LI-250). The room was otherwise darkened and draughts were excluded as far as possible. The balance was protected from air movement by cardboard baffles and readings were only taken when the room air-conditioning unit was not active. The magnetic stirrer was turned off about three minutes before readings were taken. After suspending a piece of coral in the system the position of the balance beam was adjusted by the counter balance weight and/or rotating the fixed end of the torsion wire so that the laser beam was near the appropriate end the scale. Changes in weight as aragonite skeleton was deposited result in movement of the laser beam/spot on the scale and readings were taken at intervals of about ten minutes. The course of an experiment was followed by plotting the readings on graph paper. Rates of weight gain or loss were calculated by regression analysis of series of 4-6 readings. After a set of control reading a single experimental parameter (irradiance, temperature or $\mathrm{pH}$ ) was then changed and after an hour for acclimation a new set of reading could be taken at 10 minute intervals to give a new rate. When rates of change were very low, longer periods between reading and more readings were taken.

A series of small solid aragonite cubes, cut from Agaricia skeletons (1-3mg) of which the dry weights were accurately known were prepared beforehand. Each cube was attached to a
$20 \mathrm{~cm}$ length of extremely fine monofilament consisting of a single strand from dental floss. Attachment was by dipping the end of the filament into cyanoacrylate and touching it to the cube. A cube was used to calibrate the system for each experiment by dropping it, suspended by its monofilament, carefully onto the coral's surface. The position of the laser spot on the scale with and without the aragonite cube in position was recorded. This was repeated several times and the mean displacement for the cube was calculated. From this the equivalent dry wt. of aragonite per scale unit could be calculated. The aragonite cubes were also used to verify the linearity of the scale (corresponding to a total rotation of $<4^{\circ}$ of the wire). This procedure also permitted malfunction of the balance to be detected. Generally the system was very stable and the laser spot returned to the same place even overnight, but if the laser spot did not return to its original position it was usually because of contamination on the $\mathrm{s} / \mathrm{s}$ suspension wire at its point of entry into the seawater. Replacement of the wire usually corrected the problem. Following any change of temperature, $\mathrm{pH}$ or irradiance at least an hour for acclimation was allowed. When an experimental temperature was changed and controlled to a new level the density of the seawater also changed and a recalibration of the balance was required. Corals were carefully inspected before each experiment and were rejected if there were any sign of epiphytes, encrusting organisms or unhealthy areas on the upper or lower surfaces, or if mucus was present. Once placed in the chamber the live coral was permitted to acclimate for a period of two hours, at which point adjustments were made to the balance and placement of the laser so that reading could be taken on an appropriate part of the scale. If detectable calcification was taking place an experiment could commence. If calcification was not detected (no movement in the laser spot for an hour) the coral fragment was left in the equipment until calcification started. Occasionally an overnight period of acclimation was required before calcification started. During experiments corals were 
inspected for oxygen bubbles, which tended to appear in high light conditions and if mucus was present. The balance proved to be less sensitive with larger pieces of coral so pieces of coral used in the study were kept small (mean area $1.74 \mathrm{~cm}^{2}$, mean wt $0.42 \mathrm{~g}, \mathrm{n}=56$ ). The vessels used in the study were large ( 1 or 21 beakers), so that changes in the composition of the sea water during an experiment were minimised. The greatest change affecting experiments was probably due to evaporation increasing the density of the seawater and its level relative to the torsion balance, however the changes were slow and the rate of change constant. During experiments the $\mathrm{pH}$ changed as skeleton is deposited but because the vessels were open and exchange with the surrounding air could take place and because of slow drift of the $\mathrm{pH}$ meter during longer experiments, it was felt that the $\mathrm{pH}$ could not be used other than as an approximation of conditions during an experiment. Unless stated otherwise $\mathrm{pH}$ of the seawater was generally (8.1-8.2. The $\mathrm{pH}$ was continuously monitored and the $\mathrm{pH}$ recorded for an experiment was the average of the $\mathrm{pH}$ at the beginning and end of each period of measurement. The approximate $\left[\mathrm{CO}{ }_{2}\right]$ and $\left[\mathrm{CO}_{3}\right]$ at the control and treatment $\mathrm{pH}$ used can be seen in Table 1.

To examine the role of the organic matrix in the calcification process, coral skeletons that had been stripped of their live tissue were exposed directly to seawater. A commercial dental waterpik that had been modified with a narrower jet and to work at higher pressure was used to blast away the living tissue with a jet of seawater (waterpiking). This exposes organic matrix and most recently deposited aragonite on the surface of the skeleton. Inspection with a dissecting microscope established that tissue was completely removed even from the deepest polyp cavities

For the higher calcification rates of the waterpiked coral thicker wire was used in the balance to reduce its sensitivity so that the laser spot stayed on scale. The calcification rates of the freshly waterpiked coral were not linear and a different procedure had to be used to compare control and post treatment rates. Readings of weight were taken for 4-6 hours to establish the shape of the curve. The experimental parameter was changed (temperature, $\mathrm{pH}$ or acetazolamide added) and after acclimation readings were taken to obtain the new calcification rate. Using the NCSS software, a predicted rate was obtained from the shape of the initial shape of the curve to cover the same time period as the post treatment rate. The two rates were then compared.

In order to see if there were any longer term changes in calcification rate pieces of coral skeleton that had been freshly waterpiked were suspended in seawater for at least 48 hours. Weight gain and loss were measured at normal seawater $\mathrm{pH}$ and at reduced $\mathrm{pH}$ by replacing some medium with seawater with dissolved $\mathrm{CO}_{2}$. Dried skeletons taken to Trent University, Canada, were used to determine the relationship between weight gain and loss across the $\mathrm{pH}$ range 8.2 - 6.0. For these experiments "Coralife" artificial seawater was used (for chemical analysis and chemistry see Atkinson and Bingham, 1999). A modified balance which was closed to the outside air was used. For the lower rates of loss/gain time periods of 6-12 hours were used. At least two readings of $\mathrm{pH}$ and weight gain/loss were taken at the beginning and end of each time period. Rates were calculated using regression analysis. The $\mathrm{pH}$ was measured with an Omega PHB-212 Bench pH Meter accurate to three decimal places and calibrated daily with Omega buffers. Again the average of the readings at the beginning and end of each time period was recorded as the $\mathrm{pH}$. Coral surface areas were estimated with aluminium foil (Marsh, 1970).

NCSS statistical software (Number Crunching Statistical Systems, Dr Jerry Heintze, Kaysville, Utah) was used for obtaining a best fit for the growth curves.

\section{RESULTS}

Live coral: Pieces of live Agaricia did not start calcifying until about 24 hours after collection but if newly collected pieces were 
suspended on the torsion balance overnight in the dark calcification usually started before morning. Corals appeared to be very sensitive to any changes in conditions. Changes in light level or chemistry of the water were often followed by the cessation of calcification for an hour or two or longer and many experiments had to be disbanded because calcification ceased completely, although if left overnight calcification often restarted. High light levels ( $>300 \mu \mathrm{mol} . \mathrm{s}^{-1} . \mathrm{m}^{-2}$ ) were not used in the study because of the formation of oxygen bubbles which were sometimes formed and interfered with the functioning of the balance. With irradiance of $65 \mu \mathrm{mol} . \mathrm{s}^{-1} . \mathrm{m}^{-2}$ calcification was positively correlated with temperature (Fig. 2). Over the range $27-29.5^{\circ} \mathrm{C}$ the calcification rate increased by about $15 \%$ per $1^{\circ} \mathrm{C}$ change $(n=1)$. The mean calcification rate for Agaricia agaricites increased by $60 \%$ from $0.063 \mathrm{mg} \cdot \mathrm{hr}^{-1}$. $\mathrm{cm}^{-2}$ in the dark to $0.101 \mathrm{mg} \cdot \mathrm{hr}^{-1} \cdot \mathrm{cm}^{-2}$.in ambient laboratory lighting of $15 \mu \mathrm{mol} . \mathrm{s}^{-1} \cdot \mathrm{m}^{-2}$ (T test, $\mathrm{n}=8, \mathrm{p}<0.01)$. When the irradiance level was increased to $65 \mu \mathrm{mol} . \mathrm{s}^{-1} \cdot \mathrm{m}^{-2}$ further calcification often ceased for an hour or two then sometimes increased to a higher level but often to a lower level (mean $0.80 \mathrm{mg} \cdot \mathrm{hr}^{-1} \cdot \mathrm{cm}^{-2}$, T test, $\mathrm{n}=10, \mathrm{p}>0.05$ ) than under the laboratory lighting. When the mean $\mathrm{pH}$ of the seawater was lowered from 8.2 to 7.6 the mean calcification rate increased from $0.19 \mathrm{mg} \cdot \mathrm{hr}^{-1} \cdot \mathrm{cm}^{-2}$ to 0.28 mg.hr-1. $\mathrm{cm}^{-2}$ (T test, $\left.\mathrm{n}=7, \mathrm{p}<0.05\right)$.

Waterpiked coral: Freshly waterpiked pieces of coral suspended in seawater on the torsion balance were found to have an astonishing initial calcification rate $(n=30)$ more than an order of magnitude higher than the same piece of coral when alive. For example Agaricia \#20 had a calcification rate of 0.029-0.063 mg.hr-1. $\mathrm{cm}^{-2}$ when alive but after waterpiking the initial calcification rate was over $1.0 \mathrm{mg} \cdot \mathrm{hr}^{-1} \cdot \mathrm{cm}^{-2}$. The rate however decreases exponentially with time (Fig. 3). The weight/time data give a good fit $\left(R^{2}=0.9952\right)$ to the monomolecular growth equation, $\mathrm{W}_{\mathrm{t}}=\mathrm{W}_{\max }\left(1-\mathrm{e}^{\mathrm{k} . \mathrm{t}}\right)$ and a better fit $\left(R^{2}\right.$ $=0.9987)$ to the generalized Michaelis-Menten equation from enzyme kinetics (Lopez et al. 2000), with time replacing substrate level: $\mathrm{Wt}=\left(\mathrm{W}_{\max } \cdot \mathrm{t}\right) /(\mathrm{K}+\mathrm{t})$

(Note: $\mathrm{W}_{\mathrm{t}}$ is the increase of weight at time $\mathrm{t}, \mathrm{W}_{\max }$ is the asymptotic or maximum potential value of $\mathrm{W}$ and $\mathrm{K}$ is the time for half maximum growth).

With longer ( $t>6$ hours) experiments (Fig. 4A, B, C) It became apparant that Wt does not actually reach an asymptote or maximum but continues to rise at a constant rate. The Michaelis-Menten general formula was

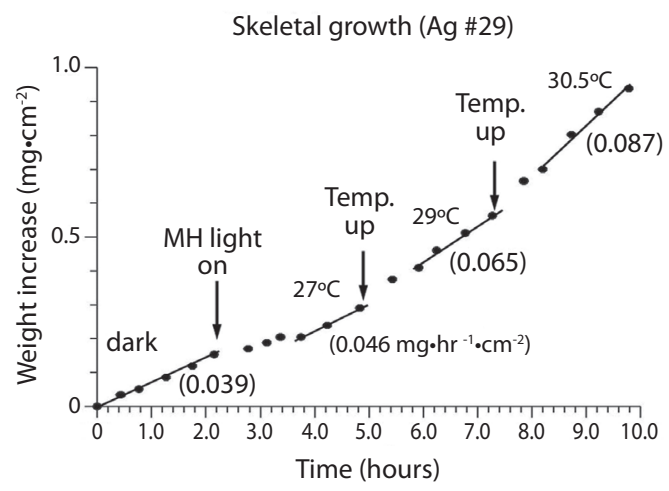

Fig. 2. Weight increase plotted against time. Calcification rates expressed in $\mathrm{mg}^{-1} . \mathrm{cm}^{-2}$ calculated from the regression lines are given in parentheses. Live Agaricia \#29 in the dark, and in the light $\left(65 \mu \mathrm{mol} \mathrm{s} \mathrm{s}^{-1} \mathrm{~m}^{-2}\right)$ at $27^{\circ} \mathrm{C}, 29^{\circ} \mathrm{C}$ and $30.5^{\circ} \mathrm{C}$.

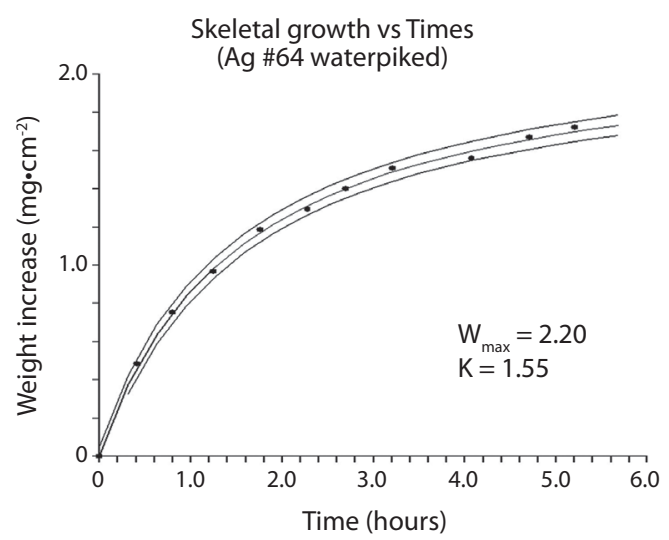

Fig. 3. Agaricia \#64, Weight increase plotted against time for a freshly waterpiked skeleton. Best fit curve for $\mathrm{W}_{\mathrm{t}}=$ $\left(\mathrm{W}_{\max } . \mathrm{t}\right) /(\mathrm{K}+\mathrm{t})$ with $\mathrm{p}=.05$ lines. 

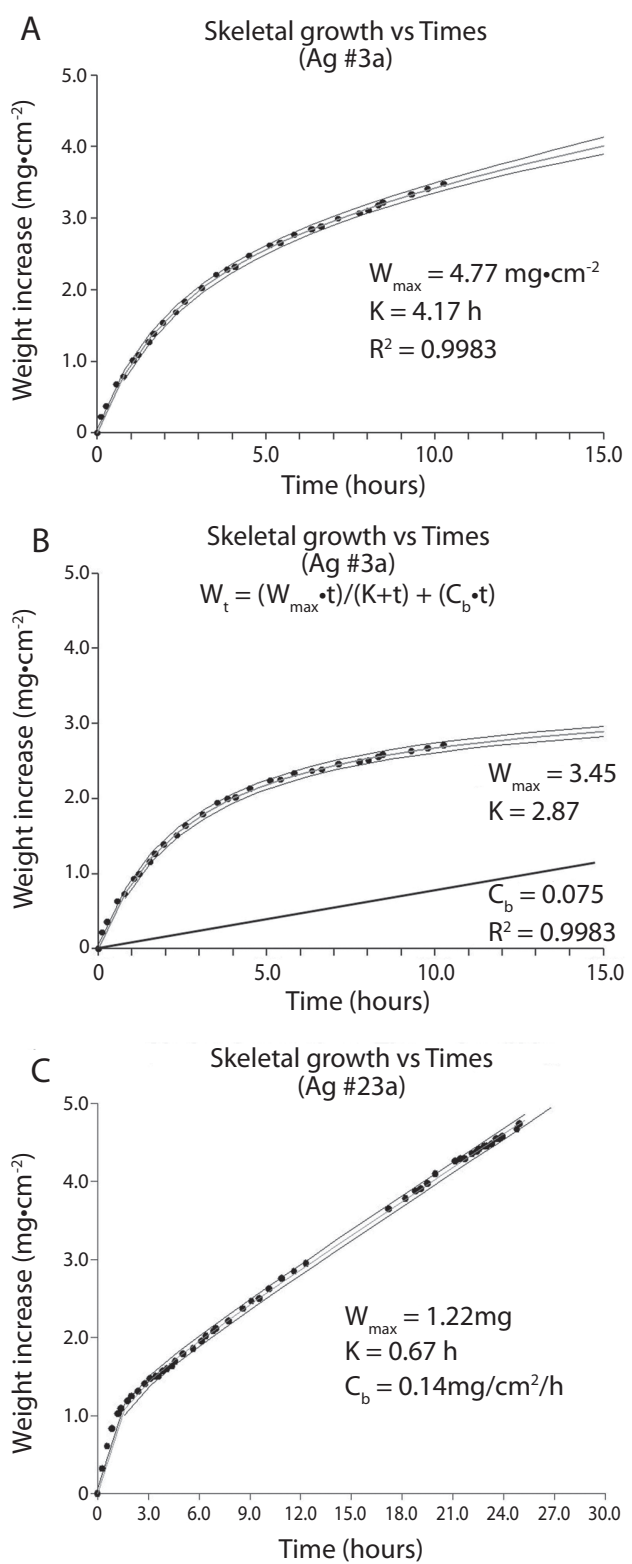

Fig. 4. Waterpiked Agaricia agaricites, Weight increases plotted against time for longer running experiments. (A) \#3a best fit curve plotted with $\mathrm{p}=0.05$ lines for $\mathrm{W}_{\mathrm{t}}=$ $\left(\mathrm{W}_{\max } \cdot \mathrm{t}\right) /(\mathrm{K}+\mathrm{t})$. (B) \#3a best fit curve plotted for $\mathrm{W}_{\mathrm{t}}=$ $\left(\mathrm{W}_{\max } \cdot \mathrm{t}\right) /(\mathrm{K}+\mathrm{t})-\mathrm{C}_{\mathrm{b}} \cdot \mathrm{t}$ with the contribution of $\mathrm{C}_{\mathrm{b}} \cdot \mathrm{t}$ plotted separately. (C) \#23a best fit curve for $\mathrm{W}_{\mathrm{t}}=\left(\mathrm{W}_{\max } \cdot \mathrm{t}\right) /(\mathrm{K}+$ $\mathrm{t})+\mathrm{C}_{\mathrm{b}}$.t showing the steady weight gain $\left(\mathrm{C}_{\mathrm{b}} . \mathrm{t}\right)$ continuing after the varying component $\left(\mathrm{W}_{\max } \cdot \mathrm{t}\right) /(\mathrm{K}+\mathrm{t})$ has reached its asymptote. modified to: $\mathrm{Wt}=\left(\left(\mathrm{W}_{\max } \cdot \mathrm{t}\right) /(\mathrm{K}+\mathrm{t})\right)+\left(\mathrm{C}_{\mathrm{b}} \cdot \mathrm{t}\right)$ where $\mathrm{Cb}$ is the constant rate of increase or slope of the line (Fig. 4B) and an even better fit to the data is obtained. For coral \# 3a (Figs. $4 \mathrm{~A}, \mathrm{~B}$. $)$ the fit to the modified formula $\left(R_{2}=\right.$ $0.9987)$ is better than that of the unmodified formula $\left(R^{2}=0.9983\right)$.

At $27^{\circ} \mathrm{C}$ (Fig. 5A) the predicted calcification rate was $0.48 \mathrm{mg} \cdot \mathrm{hr}^{-1} . \mathrm{cm}^{-2}$, compared to the actual calcification rate at $29{ }^{\circ} \mathrm{C}$ of 0.65 $\mathrm{mg} \cdot \mathrm{hr}^{-1} \cdot \mathrm{cm}^{-2}$. This represents a $17.7 \%$ increase per ${ }^{\circ} \mathrm{C}$ which is fairly close to the $15 \%$ change per ${ }^{\circ} \mathrm{C}$ for calcification obtained for live corals. The effect of changes of $\mathrm{pH}$ can be seen in Fig. 5B for a typical experiment. For a mean change of $\mathrm{pH}$ from 8.1 to 7.6 Agaricia responded with mean predicted calcification rate of $0.18 \mathrm{mg} \cdot \mathrm{hr}^{-1} \cdot \mathrm{cm}^{-2}$ compared to an actual mean calcification rate $0.32 \mathrm{mg} \cdot \mathrm{hr}^{-1} \cdot \mathrm{cm}^{-2}$. This represents a $78 \%$ increase in calcification rate ( $\mathrm{T}$ test, $\mathrm{n}=11, \mathrm{p}<.02$ ). Light did not affect the calcification rate. The initial (first hour) calcification rates of freshly waterpicked coral obtained from the NCSS curve-fitting software (Fig. 7) are shown plotted against the time of day at which each coral piece was waterpiked $(n=20)$. These results show a steady decrease in activity through the daylight light hours but a massive increase in the late afternoon.

Carbonic anhydrase: Experiments were undertaken to verify the presence of carbonic anhydrase in the exposed skeletal surface. When the carbonic anhydrase inhibitor, acetazolamide, was added to give a $100 \mu \mathrm{Mol}$ solution calcification ceased completely (Fig. 5C). Pieces of Agaricia skeleton that had been waterpiked and dried were also tested for carbonic anhydrase with the technique of Ridgeway \& Moffatt (1986). The tips of ridges and septae showed the quite distinctive blackening that indicates the presence of carbonic anhydrase (Fig. 6).

Dead coral (Waterpiked coral after soaking in seawater): A third series of experiments was undertaken to investigate what happens 

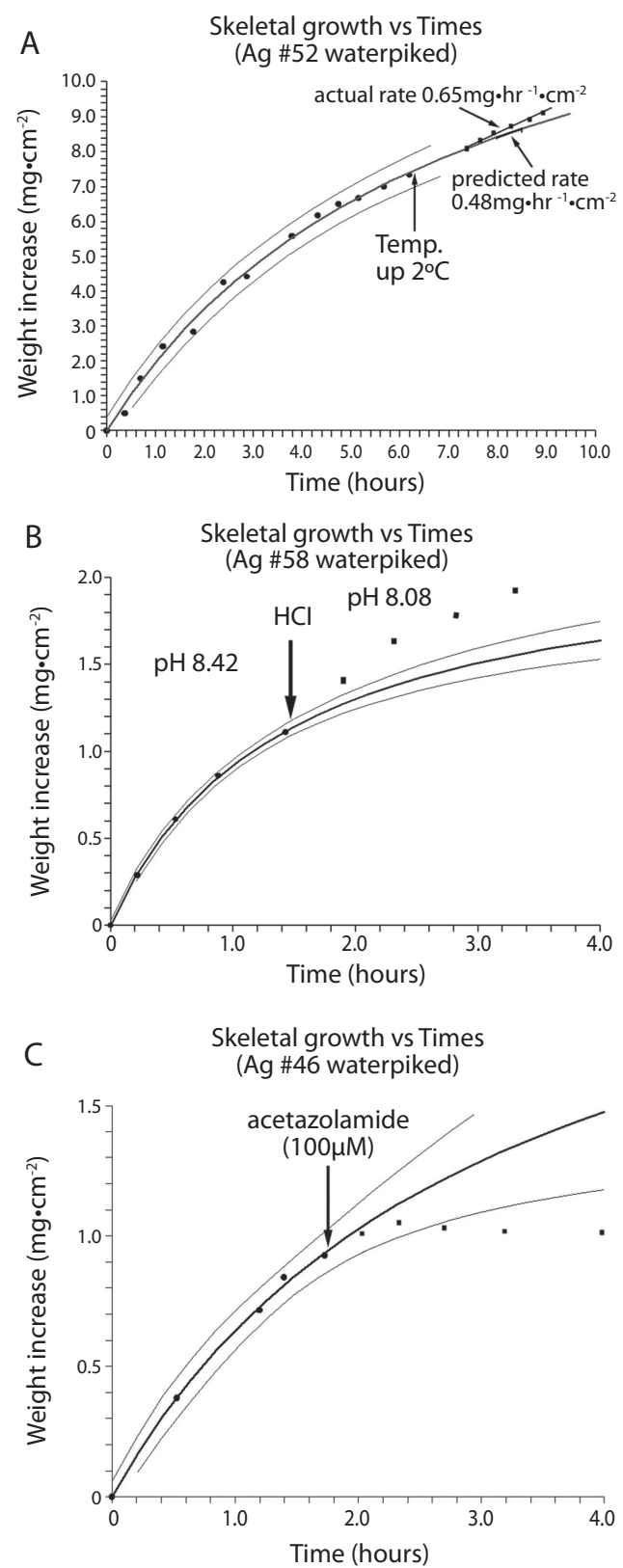

Fig. 5. Water-piked Agaricia agaricites. (A) \#28, temperature raised $2^{\circ} \mathrm{C}$ after $2 \mathrm{~h}$. (B) \#58f, $\mathrm{HCl}$ added after 1.5h. (C) acetazolamide added after $1.75 \mathrm{~h}$.

after a waterpiked coral has reached its asymptotic maximum $\mathrm{W}_{\text {max }}$. After waterpiking and suspension in seawater for 48-72 hours it was found, surprisingly, that rates of deposition

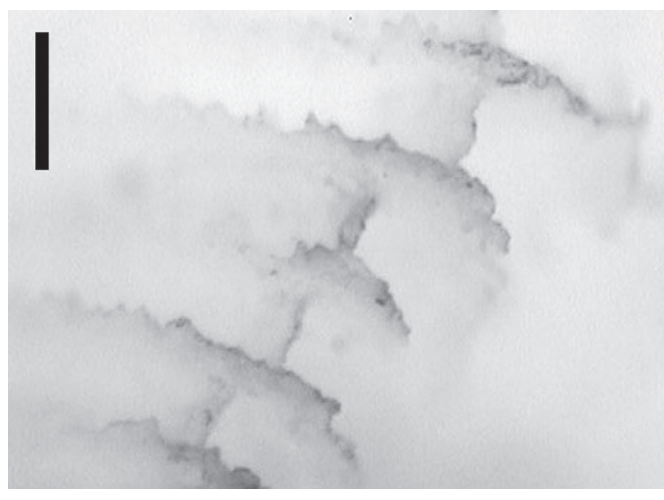

Fig. 6. Photograph of waterpiked Agaricia skeleton stained (Ridgeway and Moffett, 1986) for carbonic anhydrase. (incubation for 10 minutes in $1.75 \mathrm{mM} \mathrm{CoSO}_{4}$, rinsing and development in $0.5 \%$ ammonium sulphide for 3 minutes. The tips of ridges and septae show blackening that indicates the presence of carbonic anhydrase. Scale bar $0.05 \mathrm{~cm}$

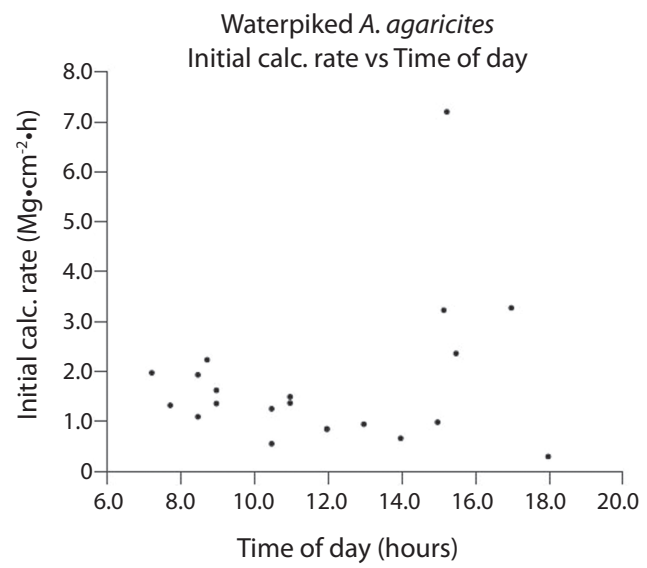

Fig. 7. Waterpiked Agaricia agaricites. Initial calcification rates plotted against time of day when waterpiked.

were linear and the same order of magnitude as those of the live coral. Unlike the situation with freshly waterpiked corals the rate of deposition this time was positively correlated with pH. (Figs. 8A, B). When the mean $\mathrm{pH}$ of the seawater was reduced from 8.2 to 7.5 the mean calcification rate decreased from 0.25 to 0.13 $\mathrm{mg} . \mathrm{h}^{-1} . \mathrm{cm}^{-2}$. This $50 \%$ reduction is statistically significant ( $\mathrm{T}$ test, $\mathrm{n}=6, \mathrm{p}<0.05$ ). With a larger change in $\mathrm{pH}$ from 8.25 to 6.5 the deposition 

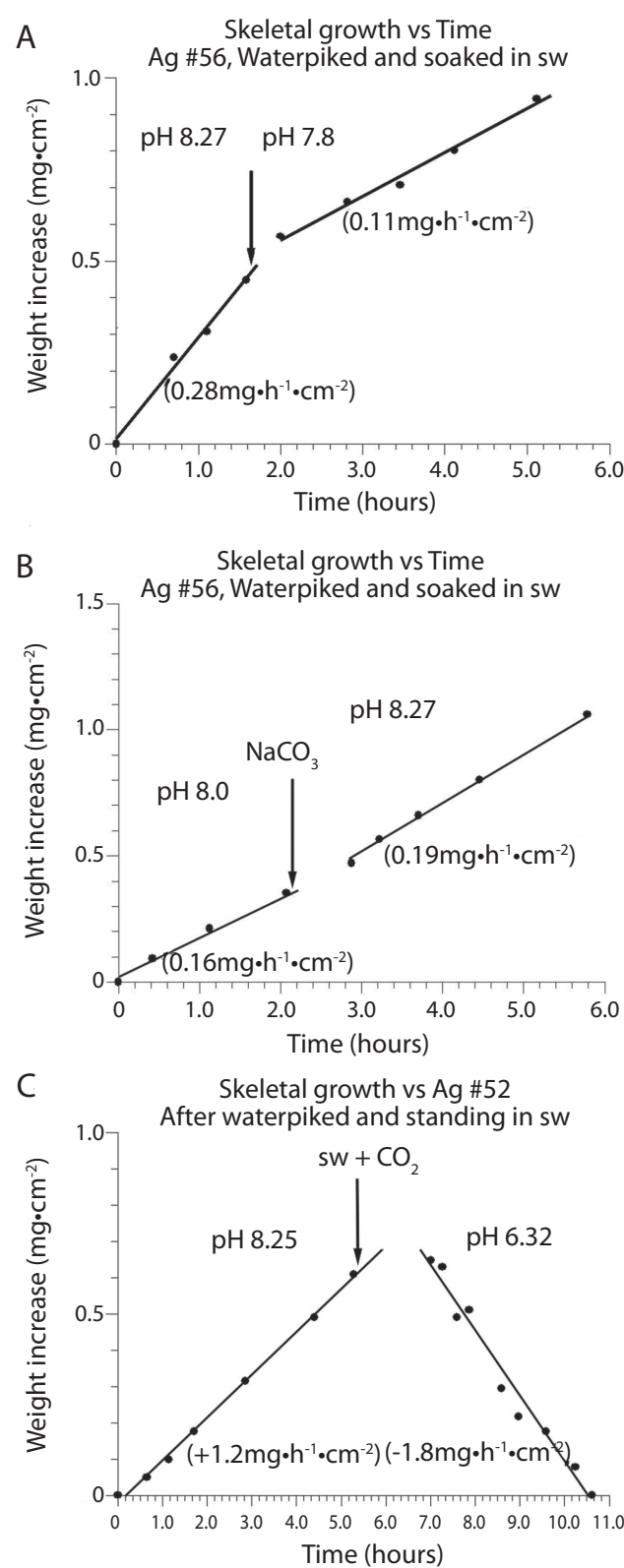

Fig. 8. Agaricia agaricites, skeleton after waterpiking and soaking in seawater, Weight increases plotted against time. Calcification rates, expressed in $\mathrm{mg}^{-1} \mathrm{~cm}^{-2}$, calculated from the regression lines, are given in parentheses. (A) \#56, before and after addition of $\mathrm{HCl}$. (B) \#64 before and after addition of $\mathrm{CaCO}_{3}$. (C) \#52 before and after a large reduction in $\mathrm{pH}$. rate $(n=1)$ (Fig. 8C) changed from a gain of $1.2 \mathrm{mg} \cdot \mathrm{hr}^{-1} \cdot \mathrm{cm}^{-2}$ to a loss of $1.8 \mathrm{mg} \cdot \mathrm{hr}^{-1} \cdot \mathrm{cm}^{-2}$. Interpolation between the two rates indicates that the point at which the change from deposition to dissolution is at around $\mathrm{pH}$ 7.5. Again the deposition rate of $\mathrm{CaCO}_{3}$ was very sensitive to temperature $(n=1)$, showing a $57 \%$ increase per ${ }^{\circ} \mathrm{C}$ but there was no change in response to changes of light. $(n=6)$. In the first of two more detailed explorations of the relationship of calcification/dissolution rate and $\mathrm{pH}$ the plot of calcification rate against $\mathrm{pH}$ (Fig. 9A) had a sigmoidal form similar to a hyperbolic sine function $\sinh =1 / 2\left(\mathrm{e}^{\mathrm{x}}-\mathrm{e}^{-\mathrm{x}}\right)$. The data (20 points)
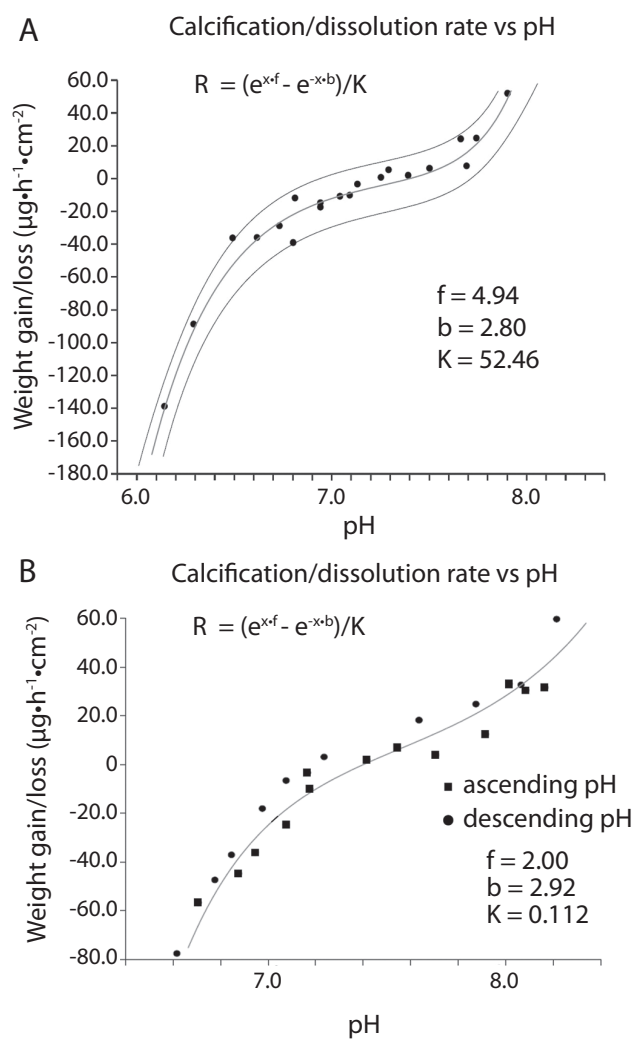

Fig. 9. Agaricia agaricites, skeleton after waterpiking and soaking in seawater. (A). Best fit curve with $\mathrm{p}=0.05$ lines. (B) Best fit curve and data points for ascending and descending $\mathrm{pH}$ change and hysteresis effect. 
give a good fit $\left(R^{2}=0.965\right)$ to the formula $\mathrm{R}=$ $\left(\mathrm{e}^{\mathrm{x} . \mathrm{f}}-\mathrm{e}^{-\mathrm{x} . \mathrm{b}}\right) / \mathrm{K}$ where $\mathrm{R}$ is the net wt gain/loss, $\mathrm{x}$ is $\mathrm{pH}_{\mathrm{r}}-\mathrm{pH}_{0}\left(\mathrm{pH}_{0}\right.$ the $\mathrm{pH}$ at which $\left.\mathrm{R}=0\right)$ and $\mathrm{f}$ and $\mathrm{b}$ are constants (comparable to reaction order or dissolution rate constants) for the forward (weight gain) and backward (weight loss) parameters and $\mathrm{K}$ is a constant. Growth/ dissolution results are commonly presented as a function of $\Omega$, for example $\mathrm{r}=\mathrm{K}(1-\Omega)^{\mathrm{n}}$ (Cubillas et al. 2005) but the treatment used here is similar to the approach of Lopez et al. (2009) and DePaulo (2011) who regard the net calcification rate $\mathrm{R}$ as the sum of the forwards rate (gain) $R_{f}$ and backwards rate (loss) $R_{b}$. The relationship between growth/dissolution and $\mathrm{pH}$ of a second Agaricia skeleton (Fig. 9B) showed the same hyperbolic sine shape but the data (23 data points) gave a less good fit to the formula $\left(R^{2}=0.730\right)$. However the difference in position of the data points from the descending $\mathrm{pH}$ changes and the ascending $\mathrm{pH}$ series are suggestive of the hysteresis effect, depending on which way their experiments were run, described by Gutjahr et al. (1996) for finely divided aragonite and calcite. In their comparison of the growth and dissolution rates of finely divided calcite and aragonite plotted against $\mathrm{pH}$ the curves, especially for aragonite, are similar to those found in this study. The $\mathrm{pH}$ at which $\mathrm{R}$ was zero for both skeletons in this study (Fig. 9A, B) was very close to a $\mathrm{pH}$ of 7.4. The same crossover point found by Gutjahr et al. (1996) was close to a $\mathrm{pH}$ of 7.8. One effect noticed in this study but not followed up was that when a piece of coral was moved into seawater of lower $\mathrm{pH}$ (eg from 8.1 to 7.5 ) the $\mathrm{pH}$ increased by about $0.01 . \mathrm{h}^{-1}$.

\section{DISCUSSION}

In the experiments in which the $\mathrm{pH}$ of the experimental medium was reduced from an average of 8.2 to 7.6 (estimated $\left[\mathrm{CO}_{2}\right]$ increases from $10.1 \mu \mathrm{mol} \mathrm{kg}{ }^{-1}$ to 49.7 while estimated $\left[\mathrm{CO}_{3}{ }^{2-}\right]$ decreases from $241.5 \mu \mathrm{mol} \mathrm{kg}{ }^{-1}$ to 75) calcification in the living corals increased significantly This provides good evidence that $\mathrm{CO}_{2}$ is the substrate for calcification rather than
$\mathrm{CO}_{3}{ }^{2-}$. The report by Lee et al. (2010) that crystalline aragonite is deposited from a solution of $\mathrm{CaCl}_{2}$ containing carbonic anhydrase using $\mathrm{CO}_{2}$ directly from the atmosphere gives further support for the possibility that $\mathrm{CO}_{2}$ can be the substrate for calcification.

Light enhanced calcification has been shown to be $3 \mathrm{x}$ the dark level (Allemand et al. 2011). This study confirms that for living Agaricia agaricites the dark calcification rate is almost doubled in very low light, but for higher light levels, results were inconsistent. In this study when light levels were increased calcification usually ceased immediately for a period of hours then settled at a new level which could be higher or lower that the original. At higher light levels oxygen bubbles interfered with the experimental technique and the hyperbolic tangent relationship between irradiance and calcification rate found by Marubini et al. (2004) or Moya et al. (2006) could not be confirmed. Sandeman (2008a) showed that the $\mathrm{Ca}^{2+}$ ATPase/proton pump may be light sensitive as suggested by Cohen \& McConnaughey (2003) and proposed (Sandeman, 2008b) that $\mathrm{H}_{2} \mathrm{O}_{2}$ produced by zooxanthellae in high light conditions makes the plasma membrane leaky to $\mathrm{Ca}^{2+}$ with the result that more $\mathrm{Ca}^{2+}$ could reach the ECM. The inconsistent response of calcification to light found in this and other studies is difficult to explain. However, if $\mathrm{CO}_{2}$ is indeed the substrate for calcification then the responses of corals to light (i.e. initially turning off calcification then adjusting to a new level) found in this study are not inconsistent with what one might expect if there is competition for $\mathrm{CO}_{2}$ between calcification and photosynthesis.

The (x25) higher initial calcification rate of the freshly waterpiked coral skeletons compared to that of the same surface while alive was astonishing. The possibility that it is the result of air bubble entrapment following waterpiking and the gradual solution of the bubbles seems unlikely given the imperforate nature of the skeleton of the thin pieces of Agaricia and the response to acetazolamide (Fig. 5C). Inspection showed the accumulation of a thin 
layer of white solid, especially on the ridges of the septa, which when scraped off contained needle shaped rather than rounded crystals, indicating aragonite rather than calcite. Another possibility is that that an enzyme or catalyst is incorporated in the exposed surface which is responsible for the high initial rate. This would be in line with the two-step mechanism proposed by Cuif \& Dauphin (2005a,b) in which the biomineralization process starts with secretion of a proteoglycan matrix in which mineralization takes place. The matrix has been shown to contain structural proteins which play a catalytic role similar to that of carbonic anhydrase (Tambutté et al. 2007), has calcium binding properties (Isa \& Okazaki 1987; Constantz \& Wiener, 1988 and Puverel et al. 2005) and acidic proteins regulating the biomineralization process and the mineralization process(Rahman \& Oomori, 2009) may involve all of these. Confirmation for the presence of carbonic anhydrase on the surface of waterpiked corals comes from the experiment involving inhibition of calcification by acetazolamide (Fig. 5C) and the demonstration by staining of carbonic anhydrase in the most rapidly growing areas of the skeleton (Fig. 6). The basic shape of the deposition versus time curves for waterpiked corals (Figs. 3, 4A, B) is probably the result of the exposed carbonic anhydrase or other active ingredients of the organic matrix being covered as new aragonite is formed. The asymptote $\mathrm{W}_{\max }$ is reached when the deposition rate is reduced to zero when all the carbonic anhydrase is obliterated by deposited aragonite. Some confirmation for this comes from the lowering of the initial calcification rate (Fig. 7) that takes place during the day. The increases seen in corals waterpiked in the late afternoon may indicate that new organic matrix may be layed down at that time. The linear component of the weight gain $\mathrm{C}_{\mathrm{b}}$ is of the same order of magnitude as the rate of weight gain of coral skeleton after soaking in seawater and this abiotic mineralization based on carbonate source appears to start directly after the removal of live tissue by waterpiking and takes place simultaneously. When $\mathrm{pH}$ was reduced from an average of 8.1 to 7.6 (estimated $\left[\mathrm{CO}_{2}\right]$ increases from $13.4 \mu \mathrm{mol} \mathrm{kg}-1$ to 49.7, while estimated $\left[\mathrm{CO}_{3}{ }^{2-}\right]$ decreases from $202.5 \mu \mathrm{mol} \mathrm{kg}^{-1}$ to 75 ) the actual calcification rates showed an increase over the predicted rate which was significant at $\mathrm{p}<0.02$ level. This indicates that, as for living coral, $\mathrm{CO}_{2}$ rather than $\mathrm{CO}_{3}{ }^{2-}$ is the form in which DIC reaches the site of calcification as suggested by McConnaughey (1989). As reported by Dauphin et al. (2006) and Tambutte et al. (2007) the enzyme activity of the organic matrix is stable, it was hardly affected by immersion in boiling water or ethyl alcohol and skeletons of corals collected the previous year showed the same ability to deposit skeleton in this non-linear manner. A small piece of Montastrea annularis skeleton from the museum collection showed some activity.

If the (x25) higher initial calcification rate of the freshly waterpiked coral skeletons compared to that of the same surface while alive is indeed the result of an enzyme or catalyst incorporation in the exposed surface it indicates that the calicoblastic layers restrict calcification and contact between the living calcifying surface and seawater delivery via a paracellular route must be small. A model that does not require a paracellular pathway is that of McConnaughey (1989) and Adkins et al. (2003). It is based on dissolved $\mathrm{CO}_{2}$ as the substrate for calcification reaching the ECM by diffusion and $\mathrm{Ca}^{2+}$ ions are transported into the ECM and protons transported out by the $\mathrm{Ca}^{2+}$ ATPase/proton pump. $\mathrm{CO}_{2}$ which can pass freely through lipid membranes reaches the ECM directly, with its passage enhanced by the $\mathrm{pH}$ difference between the ECM and calicoblastic layer created by movement of protons as the result of by the $\mathrm{Ca}^{2+}$ ATPase/proton pump. In the presence of calcium binding proteins and carbonic anhydrase in the organic matrix calcium carbonate is deposited as aragonite: $\mathrm{Ca}^{2+}+\mathrm{H}_{2} \mathrm{CO}_{3} \rightarrow \mathrm{CaCO}_{3}+2 \mathrm{H}^{+}$

After waterpiking and soaking in seawater the pieces of dead coral skeleton showed a quite different response to lower $\mathrm{pH}$. When the average $\mathrm{pH}$ was reduced from 8.2 to 7.5 
(estimated $\left[\mathrm{CO}_{2}\right]$ increases from $10.1 \mu \mathrm{mol}$ $\mathrm{kg}^{-1}$ to 49.7 , while estimated $\left[\mathrm{CO}_{3}{ }^{2-}\right]$ decreases from $241.5 \mu \mathrm{mol} \mathrm{kg} \mathrm{kg}^{-1}$ to 75 ) calcification rate decreased, indicating involvement of carbonate rather than carbon dioxide. At a $\mathrm{pH}$ of seawater greater than 7.4 pieces of coral skeleton (Figs. 9A,B) gain weight and below 7.4 lose weight. The weight gains found in this study seem to be problematical. Emerson \& Hedges (2009) state what appears to be a commonly held belief that when $\Omega>1$ precipitation should occur "but this is rare because high concentrations of $\mathrm{Mg}$. block nucleation sites on the mineral surface", the results of this study suggest otherwise. The linear component of the weight gain $\mathrm{C}_{\mathrm{b}}$ of freshly waterpiked coral is of the same order of magnitude as the rate of weight gain of coral skeleton after soaking in seawater and this abiotic mineralization based on carbonate source appears to start directly after the removal of live tissue by waterpiking and appears to be a property of non-living exposed coral. The slopes of the curves (Fig. 9A, B) above and below 0, (described by $b$ and $f$ in the equations) are different. This was also found for finely divided aragonite by Gutjhar et al. (1996). The hysteresis-like effect seen in the relationship between growth/deposition rates and $\mathrm{pH}$ (Fig. 9B), also reported by Gutjhar et al. (1996) may be the result of the $\mathrm{Ca}^{2+}$ /proton exchange reported by Villegas-Jiménez et al. (2009). In this study when coral was moved from seawater of $\mathrm{pH}$ 8.1 to seawater of $\mathrm{pH} 7.5$ there was an initial increase in $\mathrm{pH}\left(0.01 . \mathrm{h}^{-1}\right)$ indicating uptake of protons from the medium as described by Villegas-Jiménez et al. (2009). This effect as pointed out by Villegas-Jiménez et al. (2009) should be investigated because it could have important consequences for the interpretation of data in calcification studies using calcium isotopes, buoyant weighing or the alkaline anomaly techniques. Further investigation is also needed to better understand the growth/ dissolution dynamics of dead coral over a range of temperatures and $\mathrm{pH}$. This should probably be done in a closed flow-through system rather than in the open system without flow that was used in this study.
This study confirms that there are two distinct processes involved in calcification and skeletal growth. First, a "biologically controlled mineralization" process (Mann, 1983) or "organic matrix-mediated mineralization" (Allemand et al. 2011). This was seen in living and and freshly waterpiked coral skeleton and is based on the enzyme carbonic anhydrase in the organic matrix, dissolved $\mathrm{CO}_{2}$ and $\mathrm{Ca}^{2+}$. Second, the deposition and dissolution seen in the freshly waterpiked pieces soaked in seawater (dead coral skeleton) with a non-living mineralization process which is carbonate-based and probably linked to the calcium carbonate saturation state $\omega$.

In their survey of the response of corals to elevated $\mathrm{CO}_{2}$ Reynaud et al. (2003) found $-3 \%$ to $-79 \%$ changes in calcification rate. Their own experiments indicated that, at normal temperatures, there was no response to elevated $\mathrm{pCO}_{2}$ but when temperature and $\mathrm{pCO}_{2}$ were both elevated, calcification dropped by $50 \%$. Yii et al. (2009) found an increase in calcification rate for Galaxea fascicularis and a decrease for Porites cylindrica with increased $\mathrm{CO}_{2}$ levels. Muehllehner \& Edmunds (2008) reported a small $(+5 \%)$ increase in calcification rate at $29^{\circ} \mathrm{C}$ for Porites rus $(\mathrm{n}=11)$ and a larger $(+100 \%)$ increase for Pocillopora meandrina $(\mathrm{n}=9)$ with increased $\mathrm{pCO}_{2}$; however at $27^{\circ} \mathrm{C}$ there were reductions in calcification rate for both species. All other recent studies have all found reduced calcification with lower $\mathrm{pH}$ and have related calcification to $\left[\mathrm{CO}_{3}{ }^{2-}\right]$ and the carbonate-saturation state $\omega$. In this study live corals and freshly waterpiked skeletons responded to lower $\mathrm{pH}$ or (elevated $\mathrm{CO}_{2}$ ) with increased calcification indicating that the substrate for calcification is $\mathrm{CO}_{2}$. It is perhaps important to consider why this result is at odds with the majority of studies that have reported coral calcification to decrease with increased $\mathrm{pCO}_{2}$. The explanation for the different results may lie in the fact that in the present study small pieces from the growing edges of thin plates of the Agaricia agaricites, were used. These, except for the thin broken edges, were completely covered with living tissue. In other 
studies the coral colonies used in calcification studies may have had dead exposed skeleton or a more porous skeleton with internal structural spaces, or channels and cavities from boring animals and which may present a significant area of skeleton in direct contact with seawater. The rate of non-biotic carbonate based deposition is higher and it may outweigh calcification by living coral tissue and thus account for the results obtained. Using the deposition rates per unit area obtained in this study for a coral with a low live calcification rate (comparable to the mean dark rate) and for the abiotic deposition on "dead" areas at two $\mathrm{pH}$ levels it is possible to estimate the rates for different combinations of live and dead areas of skeleton (Table 2). The difference between calcification rates in seawater of $\mathrm{pH} 8.2$ and 7.8 range from $+30 \%$ for coral with no dead areas to $-21.5 \%$ for coral with $30 \%$ dead exposed surface. Increased temperature would increase this range and the difference in temperature coefficients of the two processes may explain the differing for results for different temperatures obtained for example by Muehllehner \& Edmunds (2008).

Cohen \& McConnaughey (2003) posed the question "Why do coral reefs calcify so fast?". One might also ask why corals calcify so slowly? In this study calcification rates of living pieces of Agaricia varied, at normal $\mathrm{pH}$, from a mean of $0.063 \mathrm{mg} \cdot \mathrm{hr}^{-1} \cdot \mathrm{cm}^{-2}$ in the dark to $0.19 \mathrm{mg} \cdot \mathrm{hr}^{-1} \cdot \mathrm{cm}^{-2}$ in light while potential rates for newly exposed surface is over 1.0 $\mathrm{mg} \cdot \mathrm{hr}^{-1} \cdot \mathrm{cm}^{-2}$. The reason is fairly clear, living corals build complex three dimensional structures. Structures such as the septae need high rates of deposition during formation with deposition restricted in other areas. Where and how much skeleton is deposited is controlled by the organic matrix and pattern with which the carbonic anhydrase is laid down. Sandeman (2008b) pointed out that vesicles present in the layers in contact with the skeleton are probably associated with secretion of the organic matrix, and the calicoblastic layers had the highest concentration in regions of the coral with the highest calcification rates. Similarly stained carbonic anhydrase seen in Fig. 6 is distributed with the highest concentration on the fast growing septal ridges. This adds weight to the views of Wainwright (1963) and Allemand et al. $(1989,2011)$ that it is the organic matrix that determines the patterns of calcification and provides a mechanism for realizing the complex architecture of corals. The results obtained in this study are also consistent with the hypothetical mechanism presented by Allemand et al. (2011) for the assembly of nanograins within the dynamic interface (Colfen \& Mann, 2003 ) provided by the organic matrix.

There are implications from this study for understanding what is likely to happen to corals as the result of acidification and/or warming of the world's oceans. The findings suggest that lower $\mathrm{pH}$, because $\left[\mathrm{CO}_{2}\right]$ is higher, and increased temperature, will both enhance active biotic calcification, at least to a point at which other processes such as bleaching take over. For skeleton directly exposed to seawater (dead areas of the coral), as $\mathrm{pCO}_{2}$ increases and

TABLE 2

Calcification rates $\left(\mathrm{mg} \mathrm{h}^{-1} \mathrm{~cm}^{-2}\right)$ at $\mathrm{pH} 8.2$ and 7.8 calculated for $5-30 \%$ dead area. Rates for $0 \%$ and $100 \%$ dead area for a coral with a low calcification rate were measured, other values by interpolation. Calcification Rates, $\mathrm{mg} \mathrm{h}^{-1} \mathrm{~cm}^{-2}$

\begin{tabular}{ccccc}
$\%$ dead area & $\mathrm{pH} 8.2$ & $\mathrm{pH} 7.8$ & Difference & \% Difference \\
0 & 0.092 & 0.120 & 0.028 & +30.4 \\
5 & 0.100 & 0.119 & 0.019 & +18.6 \\
10 & 0.108 & 0.117 & 0.009 & +0.08 \\
15 & 0.116 & 0.116 & 0.000 & 0.0 \\
20 & 0.124 & 0.114 & 0.100 & -0.08 \\
25 & 0.132 & 0.113 & 0.019 & -14.4 \\
30 & 0.141 & 0.111 & 0.030 & -21.5 \\
100 & 0.250 & 0.090 & 0.160 & -64 \\
\hline
\end{tabular}


$\omega$ becomes lower, dissolution will eventually take place. Once past this point temperature increase will only increase the rate of dissolution. Because of the rates and temperature coefficients involved, it is unlikely that an increase in live calcification due to temperature can outpace losses due to abiotic weight loss. For many corals, even if active live calcification is taking place dissolution of skeleton at exposed dead areas, as suggested by Rodolfo-Metalpa et al. (2011) and Ries (2011) will affect survival by seriously weakening the supporting structure. Those species with smaller areas of exposed dead surface and a stronger Calcium/ proton pump (Ries 2011) may have a better chance of survival as $\mathrm{pH}$ levels drop.

\section{RESUMEN}

La acidificaión de los océanos está alterando la calcificón de los corales. Sin embargo, el mecanismo no es todavía claro. Para explorar que controla la calcificación piezas pequeñas del borde de láminas delgadas de Agaricia agaricites fueron suspendidas de una microbalanza de torsión en agua de mar ligeramente agitada y con temperatura controlada. La tasa neta de calcificación fue monitoreada mientras se manipulaba la luz, temperatura y $\mathrm{pH}$. Las piezas de coral vivo fueron sensibles a cambios en las condiciones, especialmente de luz, y la calcificación se suspendía por una o dos horas o de un día para otro. La tasa media de calcificación aumentó de 0.06 en la oscuridad a $0.10 \mathrm{mg} \mathrm{h}^{-1} \mathrm{~cm}^{-2}$ (prueba $\mathrm{T}, \mathrm{n}=8, \mathrm{p}<0.01$ ) en luminosidad baja $\left(15 \mu \mathrm{mol} \mathrm{s}{ }^{-1} \mathrm{~m}^{-2}\right)$ y mostró una relación lineal positiva con la temperatura. Con una reducción en el $\mathrm{pH}$ promedio de 8.2 a 7.6 la tasa de calcificación media en la luz (65 $\mu \mathrm{mol} . \mathrm{s}^{-1} \cdot \mathrm{m}^{-2}$ ) aumentó de 0.19 a $0.28 \mathrm{mg} \mathrm{h}^{-1} \mathrm{~cm}^{-2}$ (prueba $\mathrm{T}, \mathrm{n}=8, \mathrm{p}<0.05$ ) indicando una dependencia de dióxido de carbono. Después de remover el tejido y exponer la superficie de los esqueletos/matriz orgánica a agua de mar, la calcificación tiene un marcada aumento inicial de más de un orden de magnitud y después decrese siguiendo una curva generalizada Michaelis-Menten de crecimiento no-lineal hasta alcanzar una tasa estable. La tasa de calcificación de esqueletos recién limpiados no estaba influenciada por la luz y estaba positivamente correlacionado con la temperatura. Pra una reducción media de $\mathrm{pH}$ de 8.1 a 7.6 la tasa media de calcificaión aumentó de 0.18 a $0.32 \mathrm{mg} \mathrm{h}^{-1} \mathrm{~cm}^{-2}$ (prueba $\mathrm{T}, \mathrm{n}=11, \mathrm{p}<0.02$ ) de nuevo indicando la dependencia en el dióxido de carbono. La calcificación cesó en la presencia de azolamida un inhibidor de la anhidrasa carbónica. Tinciones confirmaron la presencia de anhidrasa carbónica, particularmente en las crestas de los septos. Después de sumergir esqueletos sin tejido en agua de mar por 48 horas la ganancia y pérdida de peso se volvió lineal y relacionada positivamente con la temperatura. Cuando el $\mathrm{pH}$ promedio se reducía de 8.2 a 7.5 la tasa media de ganacia de peso decrecía de 0.25 a $0.13 \mathrm{mg} \mathrm{h}^{-1} \mathrm{~cm}^{-2}$ (prueba $\mathrm{T}, \mathrm{n}=6, \mathrm{p}<0.05$ ) indicando una dependencia en carbonato. $\mathrm{A}$ un $\mathrm{pH}$ de 6.5 la tasa de pérdida de peso esquelético fue de $1.8 \mathrm{mg} \mathrm{h}^{-1} \mathrm{~cm}^{-2}$. La relación entre calcificaión neta y $\mathrm{pH}$ $(\mathrm{n}=2)$ indican que la gancia de peso se vuele pérdida a $\mathrm{pH}$ 7.4. Estos experimentos confirman que la calcificación es un proceso de dos pasos, involucrando la secreción de la capa de matriz orgánica que incorpora anhidrasa carbónica para producir una superficie de calcificación activa que usa dióxido de carbono en vez de carbonato. Es también poco probable que la superficie de calcificación esté en contacto directo con el agua de mar. La depositación o disolución inorgánica del esqueleto en áreas expuestas de corales muertos en un fenómeno diferente y está relacionado a los carbonatos. El gran ámbito de resultados de este y otros estudios sobre tasas de calcificación y dióxido de carbono pueden ser explicados en términos de la razón entre las zonas vivas y muertas de los corales.

Palabras clave: calcificación de corales, $\mathrm{CO}_{2}, \mathrm{pH}$, temperatura, matriz orgánica, anhidrasa carbónica

\section{REFERENCES}

Adkins, J.F., E.A. Boyle, W B. Curry \& A. Lutringer. 2003. Stable isotopes in deep-sea corals and a new mechanism for "vital effects". Geochim. Cosmochim. Acta 67: 1129-1143.

Al-Horani, F.A., É. Tambutté \& D. Allemand 2007. Dark calcification and the daily rhythm of calcification in the scleratinian coral, Galaxea fascicularis. Coral Reefs 26: 531-53.

Allemand, D., É. Tambutté, J-P. Girard \& J. Jaubert. 1998. Organic matrix synthesis in the scleratinian coral Stylophora pistillata: role in biomineralization and potential target of the organotin tributyltin. J. Exp. Biol. 201: 2001-2009.

Allemand, D., C. Ferrier-Pagès, P. Furla, F. Houlbrèque, S. Puverel, S. Reynaud, É Tambutté, S. Tambutté, \& D. Zoccola. 2004. Biomineralisation in reef-building corals: from molecular mechanisms to environmental control. C. R. Palévol 3: 453-467.

Allemand, D., É. Tambutté, D. Zoccola \& S. Tambutté. 2011. Coral calcification, cells to reefs, p. 119-150. In Z, Dubinsky \& N. Stambler (Eds). Coral Reefs: An Ecosystem in Transition. Springer Science+Business Media, Berlin. 
Atkinson, M.J. \& C. Bingham. 1999. Elemental composition of commercial seasalts. J. Aquaricult. Aquat. Sci. 8: 39-43.

Bryan, W.H. \& D. Hill. 1941. Spherulitic crystallization as a mechanism of skeletal growth in the hexacorals. Proc. R. Soc. Queensl. 52: 78-91.

Cai, W.-J., X. Hu, W.-J. Huang, L.-Q. Jiang, Y. Wang, T.-H Peng \& X. Zhang. 2010. Alkalinity distribution in the western North Atlantic Ocean margins, J. Geophys. Res. 115, C08014, doi:10.1029/2009JC005482.

Cohen, A. \& T.A. McConnaughey. 2003. Geochemical perspectives on coral mineralization. Rev. Min. Geochem. 54: 151-187.

Cölfen, H. \& S. Mann. 2003. Higher-order organization by mesoscale self-assembly and transformation of hybrid nanostructures. Angew. Chem. Int. Ed. 42: 2350-2365.

Constantz, B.R. \& S. Weiner. 1988. Acidic macromolecules associated with the mineral phase of scleratinian coral skeletons. J. Exp. Zool. 248: 253-258.

Cubillas, P., S. Köhler, M. Prieto, C Chaïrat and E.H. Oelkers. 2005. Experimental determination of the dissolution rates of calcite, aragonite, and bivalves. Chem. Geol. 216: 59-77.

Cuif, J-P. \& Y. Dauphin. 2005a The environment recording unit in corals skeletons - a synthesis of structural and chemical evidences for a biochemically driven, stepping-growth process in fibres. Biogeosciences 2: 61-73.

Cuif, J.-P. \& Y. Dauphin. 2005b. The two-step mode of growth in the scleractinian coral skeletons from the micrometre to the overall scale. J. Struct. Biol. 150: 319-331.

Dauphin, Y., J-P. Cuif \& P. Massard. 2006. Persistent organic components in heated coral aragonitic skeletons-Implications for palaeoenvironmental reconstructions. Chem. Geol. 231: 26-37.

Davies, P. S. 1989. Short-term growth measurements of corals using an accurate buoyant weighing technique. Mar. Biol.101: 389-395.

DePaolo, D.J., 2011 Surface kinetic model for isotopic and trace element fractionation during precipitation of calcite from aqueous solutions. Geochim. Cosmochim. Acta 75: 1039-1056.

de Putron, S.J., D.C. McCorkle, A.L. Cohen \& A.B. Dillon. 2011. The impact of seawater saturation state and bicarbonate ion concentration on calcification by new recruits of two Atlantic corals. Coral Reefs 30: 321-328.

Emerson, S. \& J. Hedges. 2008. Chemical Oceanography and the Marine Carbon Cycle. Cambridge Univ., Cambridge, UK.

Erez, J., S. Reynaud, J. Silverman, K. Schneider \& D. Allemand. 2011. Coral calcification under ocean acidification and global change, p. 151-176. In Z. Dubinsky and N. Stambler (eds). Coral Reefs: An Ecosystem in Transition, Springer Science+Business Media, berlin .

Fabricius, K.E., C. Langdon, S. Uthicke, C. Humphrey, S. Noonan, G. De'ath, R. Okaziki, N Muehllehner, M.S. Glas \& J.M. Lough. 2011. Losers and winners in coral reefs acclimatized to elevated carbon dioxide concentrations. Nature Clim. Change 1: 165-169.

Franzisket, L. 1964. Die Stoffwechselintensität der Riffkorallen und ihre ökologische phylogenetische und soziologische Bedeutung. Z. Vergleich. Physiol. 49: 91-113.

Furla, P., I. Galgani, I. Durand \& D. Allemand. 2000. Sources and mechanisms of inorganic carbon transport for coral calcification and photosynthesis. J. Exp. Biol. 203: 3445-3457.

Gattuso, J-P., D. Allemand \& M. Frankignoulle. 1999. Photosynthesis and calcification at cellular, organismal and community levels in coral reefs: a review on interactions and control by carbonate chemistry. Amer. Zool. 39: 160-183.

Gischler, E. \& W. Oschmann. 2005. Historical climate variation in Belize (Central America) as recorded in scleratinian corals. Palaios 20: 159-174.

Gutjahr, A., H. Dabringhaus and R Lacmann. 1996. Studies on growth and dissolution kinetics of the $\mathrm{CaCO}_{3}$ polymorphs calcite and aragonite. I. Growth and dissolution in water. J. Crystal Growth 158: 246-309.

Helmle, K.P., R.E. Dodge, P.K. Swart, D.K. Gledhill \& C.M. Eakin. 2011. Growth rates of Florida corals from 1937 to 1996 and their responses to climate change. Nature Comm. 2: 215 doi: 10.1038/ ncomms 1222 .

Isa, Y. \& M. Okazaki. 1987. Some observations on the $\mathrm{Ca}^{2+}$-binding phospholipids from scleratinian coral skeletons. Comp. Biochem. Physiol. 87B: 507-512.

Jokiel, R.L., J.E. Maragos \& L. Franzisket. 1978. Coral Growth: buoyant weight technique. Monogr. Oceanogr. Methodol. (UNESCO) 5: 529-542. 
Jury, C.P., R.F. Whitehead \& A. Szmant. 2010. Effects of variations in carbonate chemistry on the calcification rates of Madracis auretenra (= Madracis mirabilis sensu Wells, 1973): bicarbonate concentrations best predict calcification rates. Glob. Change Biol.16: 1632-1644.

Kesling, R.V. \& F.C. Crafts. 1962. Ontogenetic increase in archimedian weight of the ostracod Clamidotheca unispinosa (Baird). Am. Midl. Nat. 68: 149-153.

Krief, S., E. J. Hendy, M. Fine, R. Yam, A.Meibom, G. L. Foster \& A. Shemesh . 2010. Physiological and isotopic responses of scleractinian corals to ocean acidification. Geochim. Cosmochim. Acta. 74 : 4988-5001.

Kleypas, J.A., R.R. Buddemeier, D. Archer, J.P. Gattuso, C. Langdon, and B.N. Opdike. 1999. Geochemical consequences of increased atmospheric carbon dioxide on coral reefs. Science 284: 118-20.

Langdon, C. 2000. Review of experimental evidence for effects of $\mathrm{CO}_{2}$ on calcification of reef builders. Proc. $9^{\text {th }}$ Int. Coral Reef Symp., Bali 2: 1091-1098.

Langdon, C. and M.J. Atkinson. 2005. Effect of elevated $\mathrm{pCO}_{2}$ on photosynthesis and calcification of corals and interactions with seasonal change in temperature/ irradiance and nutrient enrichment. J. Geophys. Res. 110, CO9S07.

Langdon, C., T. Takahashi, C. Sweeney, D. Chapman, J. Goddard, F. Marubini, H. Aceves, H. Barnett \& M. J. Atkinson. 2000. Effect of calcium carbonate saturation state on the rate of calcification of an experimental coral reef. Glob. Biogeochem. Cycles. 14: 639-654.

Langdon, C., W.S. Broecker \& D.E. Hammond. 2003. Effect of elevated $\mathrm{CO}_{2}$ on the community metabolism of an experimental coral reef. Glob. Biogeochem. Cycles 17: 1101-1114.

Lee, S., J-H. Park, D. Kwak \& K. Cho. 2010. Coral mineralization $\mathrm{CaCO}_{3}$ deposition via $\mathrm{CO}_{2}$ sequestration from the atmosphere. Cryst. Grow. Des. 10: 851-855.

Lopez, O., P. Zuddas \& D. Faivre. 2009. The influence of temperature and seawater composition on calcite crystal growth mechanisms and kinetics: Implications for $\mathrm{Mg}$ incorporation in calcite lattice. Geochim. Cosmochim. Acta 73: 337-347.

Lopez, S., J. France, W.J. Gerrits, M.S. Dhanoa, D.J. Humphries \& J. Dijkstra. 2000. A generalized MichaelisMenten equation for the analysis of growth. J. Anim. Sci. 78: 1816-1828
Mann, S. 1983. Mineralization in biological systems. Struct. Bond 54: 125-174.

Marsh, J.A. 1970. Primary productivity of reef-building calcareous red algae. Ecology 51: 255-263.

Marubini, F. \& B. Thake. 1999. Bicarbonate addition promotes coral growth. Limnol. Oceanogr. 44: 716-720.

Marubini F., H. Barnett, C. Langdon \& M.J. Atkinson. 2004. Dependence of calcification on light and carbonate ion concentration for the hermatypic coral Porites compressa. Mar. Ecol. Prog. Ser. 220: 153-162.

McConnaughey, T.A. $1989 .{ }^{13} \mathrm{C}$ and ${ }^{18} \mathrm{O}$ isotopic disequilibrium in biological carbonates. II. In vitro simulation of kinetic isotope effects. Geochim. Cosmochim. Acta 53: 163-171.

McConnaughey, T.A. 2000. Community and environmental influences on reef coral calcification. Limnol. Oceanogr. 45: 1667-1671.

Moya, A., S. Tambutté, E. Tambutté, D. Zoccola, N. Camaniti \& D. Allemand. 2006. Study of calcification during a daily cycle of the coral Stylophora pistillata: implications for 'light enhanced calcification'. J. Exp. Biol. 209: 3413-3419.

Muehllehner, N. \& P.J. Edmunds. 2008. Effects of ocean acidification and increased temperature on skeletal growth of two scleratinian corals, Pocillopora meandrina and Porites rus. Proc. $11^{\text {th }}$ Int. Coral Reef Symp. ,Ft. Lauderdale 3: 57-61.

Puverel, S., E. Tambutté, L. Pereira-Mouriès, D. Zoccola, D. Allemand \& S. Tambutté. 2005. Soluble organic matrix of two scleratinian corals: Partial and comparative analysis. Comp. Biochem. Physiol. 141B: 480-487.

Rahman, M.A. \& T. Oomori. 2009. In vitro regulation of $\mathrm{CaCO}_{3}$ crystal growth by the highly acidic proteins of calcitic sclerites in soft coral, Sinularia polydacta. Connect. Tiss. Res. 50: 285-293.

Reynaud, S., N. Leclercq, S. Romaine-Lioud, C. FerrierPages, J. Jaubert \& J.-P. Gattuso. 2003. Interacting effects of $\mathrm{CO}_{2}$ partial pressure and temperature on photosynthesis and calcification in a scleractinian coral. Glob. Change Biol. 9: 1660-1668.

Ridgway, R. L. \& D. F. Moffett, 1986. Regional differences in the histochemical localization of carbonic anhydrase in the midgut of tobacco hornworm (Manduca sexta). J. Exp. Zool. 237: 407-412. 
Ries, J. 2011. Acid ocean cover up. Nature Clim. Change. 1: 294-295.

Rodolfo-Metalpa, R., S. Martin, C. Ferrier-Pagés \& J-P. Gattuso. 2010. Response of the temperate coral Cladocera caespitosa to mid- and long term exposure to $\mathrm{pCO}_{2}$ and temperature levels projected for the year 2100. Biogeosciences 7:289-300.

Rodolfo-Metalpa, R., F. Houlbréque, É. Tambutte, F. Boisson, C. Baggini, F.P. Patti, R. Jeffree, M. Fine, A. Foggo, J.P. Gattuso \& J.M. Hall-Spencer. 2011. Coral and mollusc resistance to ocean acidification adversely affected by warming. Nature Clim. Change 1: $308-312$

Sandeman, I.M. 2008a. Fine banding in the septa of corals. Proc. $11^{\text {th }}$. Int. Coral Reef Symp., Ft. Lauderdale 3: $57-61$.

Sandeman, I.M. 2008b. Light driven lipid peroxidation of coral membranes and a suggested role in calcification. Rev. Biol. Trop. 56 (Suppl. 1): 1-9.
Smith, S.V. \& G.S. Key. 1975. Carbon dioxide and metabolism in marine environments. Limnol. Oceanogr. 20: 493-495.

Tambutté, S., É. Tambutté, D. Zoccola, N. Camaniti, S. Lotto, A. Moya, D. Allemand \& J. Adkins. 2007. Characterization and role of carbonic anhydrase in the calcification process of the azooxanthellate coral Tubastrea aurea. Mar. Biol. 151: 71-83.

Villegas-Jiménez, A. Mucci \& J. Paquette. 2009. Proton/ calcium ion exchange behavior of calcite. Phys. Chem. Chem. Phys. 11: 8895-8912.

Wainwright, S.A. 1963. Skeletal organization in the coral Pocillopora damicornis. Quart. J. Micros. Sci. 104: 164-183.

Yii, S.-H., A. Munafi, A. Bolong, T.-T. Yang \& H.-C. Liew. 2009. Effect of elevated carbon dioxide on two scleractinian corals: Porites cylindrica (Dana, 1846) and Galaxea fascicularis (Linnaeus, 1767). J. Mar. Biol. 2009: doi:10.1155/2009/215196. 